\title{
Uptake and antiproliferative effect of molecular iodine in the MCF-7 breast cancer cell line
}

\author{
O Arroyo-Helguera, B Anguiano, G Delgado and C Aceves
}

Instituto de Neurobiología, Universidad Nacional Autónoma de México, Campus Juriquilla Km 15 Carretera Qro-SLP, Juriquilla, 76230 Querétaro, México

(Requests for offprints should be addressed to C Aceves; Email: caracev @ servidor.unam.mx)

\begin{abstract}
This study analyzes the uptake and antiproliferative effect of two different chemical forms of iodine, iodide $\left(I^{-}\right)$and molecular iodine $\left(I_{2}\right)$, in MCF-7 cells, which are inducible for the $\mathrm{Na}^{+} / \mathrm{I}^{-}$symporter (NIS) and positive for pendrin (PDS). The mouse fibroblast cell line NIH3T3 was used as control. Our results show that in MCF-7 cells, $\mathrm{I}^{-}$uptake is sustained and dependent on NIS, whereas $\mathrm{I}_{2}$ uptake is transient with a maximal peak at $10 \mathrm{~min}$ and a final retention of $10 \%$ of total uptake. In contrast, no $\mathrm{I}^{-}$was taken up by $\mathrm{NIH} 3 \mathrm{~T} 3$ cells, and although $\mathrm{I}_{2}$ was captured with the same time pattern as in MCF-7 cells, its uptake was significantly lower, and it was not retained within the cell. The uptake of $\mathrm{I}_{2}$ is independent of NIS, PDS, $\mathrm{Na}^{+}$, and energy, but it is saturable and dependent on protein synthesis, suggesting a facilitated diffusion system. Radioiodine was incorporated into protein and lipid fractions only with $\mathrm{I}_{2}$ treatment. The administration of non-radiolabeled $\mathrm{I}_{2}$ and 6-iodo-5-hydroxy-8,11,14-eicosatrienoic acid (6-iodolactone, an iodinated arachidonic acid), but not KI, significantly inhibited proliferation of MCF-7 cells. Proliferation of NIH3T3 cells was not inhibited by $20 \mu \mathrm{M} \mathrm{I}_{2}$. In conclusion, these results demonstrate that $I_{2}$ uptake does not depend on NIS or PDS; they suggest that in mammary cancer cells, $\mathrm{I}_{2}$ is taken up by a facilitated diffusion system and then covalently bound to lipids or proteins that, in turn, inhibit proliferation.
\end{abstract}

Endocrine-Related Cancer (2006) 13 1147-1158

\section{Introduction}

All vertebrates concentrate iodide $\left(\mathrm{I}^{-}\right)$in the thyroid gland for thyroid hormone (TH) synthesis (Carrasco 2000, Pisarev \& Gartner 2000). The mechanism of $\mathrm{I}^{-}$ uptake involves active and passive transport systems present in several organs, including thyroid and mammary glands (Carrasco 2000, Soleimani et al. 2001, Rillema \& Hill 2003a, Gillan et al. 2004). The active transport is mediated by $\mathrm{Na}^{+} / \mathrm{I}^{-}$symporter (NIS), which is a transmembrane glycoprotein that transports $\mathrm{I}^{-}$against its concentration gradient and is perchlorate $\left(\mathrm{KClO}_{4}\right)$ sensitive (Eskandari et al. 1997, Carrasco 2000). In lactating animals, NIS actively transports $\mathrm{I}^{-}$from the maternal plasma to the alveolar epithelial cells of the mammary gland (Tazebay et al. 2000). In the human breast cancer cell line MCF-7, retinoic acid (RA) treatment increases NIS mRNA, NIS protein, and iodide uptake (Kogai et al. 2000).
Pendrin (PDS) is a facilitated diffusion transporter that is sensitive to disulfonic-2,2' ${ }^{\prime}$-stilbene- $4,4^{\prime}$-diisotiocianic acid (DIDS). PDS is also involved in $\mathrm{I}^{-}$uptake and has been described in thyroid and mammary gland as well as in immortalized cell lines such as normal rat thyroid FRTL-5 (Royaux et al. 2000) and in several human breast cancer cell lines (Shennan 2001, Rillema \& Hill 2003b, García-Solís et al. 2005a,b).

With regard to $\mathrm{I}_{2}$ uptake, studies in brown algae show that $\mathrm{I}^{-}$uptake is dependent on oxidation, i.e. the $\mathrm{I}^{-}$in seawater is oxidized to $\mathrm{I}_{2}$ or hypoiodous acid (HIO) by exohaloperoxidases and then penetrates into algal cells by means of a facilitated diffusion system (Küpper et al. 1998). Thyroid cancer cells transfected with the exoenzyme thyroperoxidase (TPO) or with both NIS and TPO (NIS/TPO) incorporate ${ }^{125} \mathrm{I}^{-}$into proteins, but cells transfected only with NIS do not. Moreover, in the presence of specific inhibitors of NIS or TPO, uptake and 
protein organification of ${ }^{125} \mathrm{I}^{-}$is strictly dependent on TPO but not on NIS (Wenzel et al. 2003). These studies suggest that ${ }^{125} \mathrm{I}^{-}$is oxidized by TPO but does not use NIS to enter in the cell. Recent studies in our laboratory have shown that normal rat mammary glands and tumors take up $\mathrm{I}_{2}$ even in presence of $\mathrm{KClO}_{4}$ or furosamide, suggesting that $\mathrm{I}_{2}$ uptake does not depend on NIS or PDS respectively (García-Solís et al. 2005a,b). Several studies support the idea that the biological effect of $\mathrm{I}^{-}$is mediated by iodinated derivatives, for example, $\mathrm{I}^{-}$ supplementation of cultured thyrocytes inhibits cell proliferation and induces apoptosis, effects shown only if TPO activity is present. Moreover, Vitale et al. (2000) showed that if TPO activity is blocked with 6-n-propyl2-thiouracil (PTU), the apoptotic $\mathrm{I}^{-}$effect is eliminated. In addition, in lung cancer cells transfected with NIS or NIS/TPO, the apoptotic effect is induced only in NIS/TPO transfected cells treated with $\mathrm{I}^{-}$(Zhang et al. 2003). These data indicated that $\mathrm{I}^{-}$must be oxidized in order to have a cytotoxic effect. In thyroid, this effect is mediated by iodinated arachidonic acid (AA) derivatives called: 6-iodo-5-hydroxy-8,11,14-eicosatrienoic acid or 6-iodolactone (6-IL) and/or by iodohexadecanal (Dugrillon et al. 1990, Pisarev et al. 1994, Langer et al. 2003). In mammary gland, iodine deficiency is involved in dysplasias (Eskin et al. 1995, Aceves et al. 2005), which are reversible with $\mathrm{I}_{2}$ but not with $\mathrm{I}^{-}$administration (Eskin et al. 1995). Recent data generated in our laboratory showed that continuous treatment with $\mathrm{I}_{2}$, but not with $\mathrm{I}^{-}$, has a potent antineoplasic effect on tumoral progression in $\mathrm{N}$-methyl- $\mathrm{N}$-nitrosourea-treated virgin rats (García-Solís et al. 2005a,b). The lack of $\mathrm{I}^{-}$effect has been explained by the fact that lactoperoxidase, the enzyme that oxidizes $\mathrm{I}^{-}$and covalently binds it to the milk protein, casein, is expressed in mammary gland only when this tissue is lactating (Strum 1978, Shah et al. 1986). In agreement with our findings, Shrivastava et al. (2006) reported that $I_{2}$ treatment causes apoptosis in several human breast cancer cell lines but not in normal human peripheral blood lymphocytes. They showed the involvement of apoptosis-inducing factor (AIF) from mitochondria, which caused nuclear fragmentation independent of caspases. However, neither the $\mathrm{I}_{2}$-uptake mechanism nor iodolipid formation has been investigated in mammary cells.

In this study, we used MCF-7 cells to test the participation of NIS and PDS in $\mathrm{I}_{2}$ uptake as well as its saturability and dependence on mechanisms, such as transcription, translation, $\mathrm{Na}^{+}$, and energy. We also analyzed iodine incorporation into proteins or lipids (organification) and the effect of $\mathrm{I}_{2}, \mathrm{I}^{-}$, and 6-IL on cellular proliferation.

\section{Materials and methods}

\section{Materials and cell culture}

Dulbecco's modified Eagle's medium (DMEM), Hank's balanced salt solution (HBSS), fetal bovine serum (FBS), penicillin, streptomycin, and trypsinEDTA solutions were supplied by GIBCO-BRL (Grand Island, NY, USA). All trans-retinoic acid, DIDS, arachidonic acid, 3-(4,5-dimethylthiazol-2yl-)2,5-diphenyl tetrazolium bromide (MTT), sodium azide, thimerosal, $\alpha$-amanitin, and silica gel were purchased from SIGMA Chemical Co. Cycloheximide (CHX) was obtained from Calbiochem (La Jolla, CA, USA). PTU was supplied by US Biochemical Co. (Cleveland, OH, USA). All other reagents were obtained from SIGMA Chemical Co. The breast cancer cell line MCF-7 (ATCC HTB-22) and mouse fibroblast cell line NIH3T3 (ATCC CRL-1658) were kindly supplied by Instituto Nacional de Cancerología de México and Instituto de Neurobiologías respectively. Cells were grown in DMEM supplemented with $10 \%$ (v/v) FBS, $100 \mathrm{U} / \mathrm{ml}$ penicillin, and $100 \mu \mathrm{g} / \mathrm{ml}$ streptomycin (basal medium) at $37^{\circ} \mathrm{C}$ and $5 \% \mathrm{CO}_{2}$ for $24 \mathrm{~h}$ before treatments.

\section{NIS induction and RT-PCR}

To induce NIS, the cells were grown in six-well dishes in basal medium for $24 \mathrm{~h}$, the medium was changed to HBSS and the cells were untreated or treated with $1 \mu \mathrm{M}$ RA for $48 \mathrm{~h}$ at $37^{\circ} \mathrm{C}$. After incubation, total RNA was extracted using TRIzol reagent (Life Technologies, Inc.,) according to the manufacturer's instructions. To amplify 453 bp NIS, 625 bp PDS, and 545 bp glyceraldehyde-3-phosphate dehydrogenase (GAPDH) cDNA fragments, PCR primers with the sequences shown in Table 1 were used. GAPDH served as a control of RNA quantity and integrity, and the reverse transcriptase (RT)-PCR was carried out as described previously (Arroyo-Helguera et al. 2005). The samples were first denatured at $94{ }^{\circ} \mathrm{C}$ for $45 \mathrm{~s}$, followed by $32 \mathrm{PCR}$ cycles, each with temperature variations as follows: $94^{\circ} \mathrm{C}$ for $45 \mathrm{~s}, 54.5^{\circ} \mathrm{C}(\mathrm{GAPDH}$ and NIS) or $60^{\circ} \mathrm{C}$ (PDS) for $45 \mathrm{~s}$, and $72{ }^{\circ} \mathrm{C}$ for $1 \mathrm{~min}$. The last cycle was followed by an additional extension incubation of $3 \mathrm{~min}$ at $72{ }^{\circ} \mathrm{C}$. The amplicons were resolved in a $2 \%$ agarose gel and visualized with ethidium bromide under a u.v. transilluminator. The sizes of the bands were confirmed by comparison with a commercial DNA ladder (1 kb DNA ladder, GIBCO-BRL). 


\begin{tabular}{lll}
\hline mRNA & $\begin{array}{l}\text { GenBank } \\
\text { accession no. }\end{array}$ & Sense/antisense primer sequence $\left(5^{\prime}\right.$ at $\left.3^{\prime}\right)$ \\
\hline GAPDH, nt. 472-1017 & BC083511 & GACAACAGCCTCAAGATCATCAG/TTGCTGTAGCCAAATTCGTTGTAC \\
PDS, nt. 1928-2553 & AF030880 & CACAGTTGGATTTGATGCCACTAGAGTA/TACGCATAGCCTCATCCTGGACAT \\
NIS, nt. 630-1083 & NM-000453 & CTTCTGAACTCGGTCCTCAC/GAGCCGCTATACATTCTGGA \\
\hline
\end{tabular}

\section{Radioiodine-uptake assay}

The procedure has been described (Kogai et al. 2000) but was used with minor modifications. Briefly, the cells were treated with or without RA and then incubated with $2.0 \mathrm{ml}$ HBSS containing either $0.005 \mu \mathrm{Ci}$ of carrier-free $\mathrm{Na}^{125} \mathrm{I}\left({ }^{125} \mathrm{I}^{-}\right.$; NEN Life Science Products, Boston, MA, USA) and $2 \mu \mathrm{M}$ KI or $0.005 \mu \mathrm{Ci}$ of ${ }^{125} \mathrm{I}_{2}$ (obtained by the oxidation of ${ }^{125} \mathrm{I}^{-}$to ${ }^{125} \mathrm{I}_{2}$ with $\mathrm{H}_{2} \mathrm{O}_{2}$ and $\mathrm{HCl}$ as described by McAlpine (1945)) and $2 \mu \mathrm{M} \mathrm{I}_{2}$ (the final specific activity was $1.25 \mathrm{mCi} / \mathrm{mmol}$ in both cases). At the end of $2.5,5,10,15,30$, and $60 \mathrm{~min}$ incubation, the plates were placed on ice, HBSS containing ${ }^{125} \mathrm{I}^{-}$or ${ }^{125} \mathrm{I}_{2}$ was removed, and the cells were washed twice with $1 \mathrm{ml}$ ice-cold PBS. The cells were scraped with $1 \mathrm{ml}$ PBS, and the radioactivity was measured in a $\gamma$-counter. For uptake kinetics, the cells were incubated for $5 \mathrm{~min}$ with $0.005 \mu \mathrm{Ci}{ }^{125} \mathrm{I}_{2}$ and $0.1-10 \mu \mathrm{M}$ unlabeled $\mathrm{I}_{2}$.

\section{Effect of $\mathrm{KCIO}_{4}$ and DIDS on $\mathrm{I}_{2}$ uptake}

To analyze the participation of NIS or PDS in $\mathrm{I}_{2}$ uptake, cells with and without RA were preincubated for $15 \mathrm{~min}$ with $\mathrm{KClO}_{4}(5-50 \mu \mathrm{M})$ or DIDS (0.1-1 mM) respectively. ${ }^{125} \mathrm{I}_{2}$ or ${ }^{125} \mathrm{I}^{-}(1.25 \mathrm{mCi} / \mathrm{m}$ mol) was added to the medium, and it was kept at $37^{\circ} \mathrm{C}$ for $15 \mathrm{~min}$. After incubation, the cells were washed with PBS, and the radioactivity detected was normalized to $10^{4}$ cells.

\section{Effect of transcription, translation, and metabolic inhibitors on $I_{2}$ uptake}

To determine the effect of inhibiting RNA and protein synthesis on $\mathrm{I}_{2}$ uptake, the cells were preincubated for 30,60 , and $120 \mathrm{~min}$ in the presence or in the absence of $5 \mu \mathrm{g} / \mathrm{ml} \mathrm{CHX}$ or $5 \mu \mathrm{g} / \mathrm{ml} \alpha$-amanitin, washed with PBS to remove the drugs, and subsequently incubated with $1.25 \mathrm{mCi} / \mathrm{mmol}{ }^{125} \mathrm{I}_{2}$ at $37^{\circ} \mathrm{C}$ for $15 \mathrm{~min}$. For metabolic inhibition, the cells were preincubated at $37^{\circ} \mathrm{C}$ for $30 \mathrm{~min}$ in HBSS with and without $10 \mathrm{mM}$ sodium azide or thimerosal. After washing twice, the cells were incubated with $1.25 \mathrm{mCi} / \mathrm{mmol}{ }^{125} \mathrm{I}_{2}$ or ${ }^{125} \mathrm{I}^{-}$at $37{ }^{\circ} \mathrm{C}$ for $15 \mathrm{~min}$.

\section{${ }^{125} \mathrm{I}_{2}$ and ${ }^{125} \mathrm{I}^{-}$organification into proteins and lipids}

The cells were treated with $100 \mu \mathrm{M}$ PTU, a TPO inhibitor, $5 \mathrm{~min}$ before adding $1.25 \mathrm{mCi} / \mathrm{mmol}{ }^{125} \mathrm{I}_{2}$ or ${ }^{125} \mathrm{I}^{-}$in HBSS medium; after 15 or $60 \mathrm{~min}$, the cells were lyzed with SDS-PAGE sample buffer containing the proteinase inhibitor cocktail Mini Complete (Roche) or precipitated with $10 \%$ trichloroacetic acid (TCA). The lipid fraction was extracted according to the procedure described by Bligh \& Dyer (1959), and the radioactivity accumulated in the fractions was measured and expressed in c.p.m. $/ 10^{6}$ cells. The protein concentration in SDS-PAGE buffer lysates from cells treated with or without PTU was estimated using the Bradford assay (Bio-Rad); aliquots containing $50 \mu \mathrm{g}$ protein were heated at $70{ }^{\circ} \mathrm{C}$ for $3 \mathrm{~min}$ in $1 \times$ SDS gel loading buffer $(10 \%$ glycerol, $2 \%$ SDS, $62.5 \mathrm{mM}$ Tris- $\mathrm{HCl}(\mathrm{pH}$ 6.8) with 2-mercaptoethanol) to reduce and denature protein and then separated by SDS-PAGE on $12 \%$ gels. Lipids were resolved by ascending thin-layer chromatography (TLC) using aluminium TLC sheets (silica gel 60 F254, layer thickness $0.2 \mathrm{~mm}$, Merck) and dichloromethane $\left(\mathrm{CH}_{2} \mathrm{Cl}_{2}\right)$, methanol (MeOH; 97.5:2.5\% (v/v)) as solvent system. Lipids were visualized in an $\mathrm{I}_{2}$ vapor chamber and were identified by comparison with the standards of arachidonic acid (AA) and its 6-IL derivative run on the same plates. Radioiodinated proteins or lipids were exposed with a phosphor-intensifying screen and scanned in a Storm phosphoimager (Applied Biosystem). The masses of the protein bands were estimated by comparison with commercial molecular weight markers (high-range rainbow molecular weight markers 14.3-220 kDa, Amersham Biosciences).

\section{Synthesis of the 6-IL}

The 6-IL was synthesized as described (Monteagudo et al. 1990). Briefly, $67 \mathrm{mg}$ AA in $8.5 \mathrm{ml}$ tetrahydrofuran and water $(5 \mathrm{ml})$ was treated at $0{ }^{\circ} \mathrm{C}$ with potassium bicarbonate $(50 \mathrm{mg})$, potassium iodide $(133 \mathrm{mg})$, and $\mathrm{I}_{2}(203 \mathrm{mg})$ with continuous stirring for 4 days at $4{ }^{\circ} \mathrm{C}$ while protected from light. We then added saturated sodium thiosulfate solution. The radioactive iodolactone was synthesized by incubating $1 \mathrm{mCi}^{125} \mathrm{I}^{-}$and $2.5 \mu \mathrm{l}$ chloramine- $\mathrm{T}(0.5 \mathrm{mg} / \mathrm{ml}$ 
in $50 \mathrm{mM}$ PBS) with $40 \mathrm{mg}$ AA in $8 \mathrm{ml}$ acetonitrile for $4 \mathrm{~h}$ at $0{ }^{\circ} \mathrm{C}$. The product was extracted with $\mathrm{CH}_{2} \mathrm{Cl}_{2}$, washed with water, and dried with anhydrous sodium sulfate. The crude product was subjected to flash chromatography on silicagel (particle size, 230-400 mesh $60 \AA$ ). Elution was with $\mathrm{CH}_{2} \mathrm{Cl}_{2}: \mathrm{MeOH}$ $(97.5: 2.5 \%, \mathrm{v} / \mathrm{v})$, fractions $(5 \mathrm{ml})$ were collected and evaporated to dryness under nitrogen. Their purity was checked by TLC using $\mathrm{CH}_{2} \mathrm{Cl}_{2}$ : $\mathrm{MeOH}$ $(97.5: 2.5 \%, v / v)$, and the spots were detected with $\mathrm{I}_{2}$ vapor and autoradiography.

\section{Determination of cell proliferation}

The effects of $\mathrm{I}^{-}, \mathrm{I}_{2}$, and 6-IL on cell proliferation were investigated using Trypan Blue dye exclusion and methylthiazolyldiphenyl-tetrazolium bromide (MTT) cell proliferation assays. The cells $\left(3 \times 10^{5}\right.$ cells/well $)$ were cultured in DMEM supplemented with $1 \%$ FBS on six-well culture plates. The cells were then incubated with $\mathrm{KI}$ or $\mathrm{I}_{2}(2-100 \mu \mathrm{M})$ and 6-IL $(0.1-1 \mu \mathrm{M})$. Control cells were treated with water or with $0.1 \%$ ethanol, the solvents for the two iodine forms or 6-IL respectively. After 24, 48, and $72 \mathrm{~h}$ treatment, the cells were harvested with trypsin-EDTA. Trypan blue $(0.4 \%)$ was added, and viable cells that excluded the dye were counted with a hemocytometer under the microscope. MTT was used for the cytotoxic evaluation. This assay is based on the conversion by viable cells of the yellow tetrazolium dye MTT to purple formazan crystals, and it provides an indirect, but quantitative determination of metabolically active cells. Briefly, the cells were seeded in a 96-well plate at a density of $5 \times 10^{3}$ cells/well and incubated for $24 \mathrm{~h}$. After removing the medium, $200 \mu \mathrm{l}$ fresh medium per well was added together with $\mathrm{KI}_{\text {or }} \mathrm{I}_{2}(20 \mu \mathrm{M})$ and 6IL $(0.5 \mu \mathrm{M})$. After 24,48 , and $72 \mathrm{~h}, 10 \mu \mathrm{MTT}(5 \mathrm{mg} / \mathrm{ml}$ in PBS) were added to the wells, and the plate was incubated for $30 \mathrm{~min}$ at $37^{\circ} \mathrm{C}$ in the dark. The medium was removed and $100 \mu \mathrm{l}$ dimethyl sulfoxide was added to the wells, and the absorbance was measured at $550 \mathrm{~nm}$ using the SpectraCount ELISA reader. The percentage of proliferation was calculated by the equation

$\%$ proliferation $=[($ test cell OD-control cell OD $) /$

$$
\text { control cell OD] } \times 100 \text {. }
$$

\section{Statistical analysis}

The data were mean values of at least three different experiments and expressed as mean \pm s.D. Differences between experimental groups were analyzed using a one-way ANOVA and Tukey's test and differences with $P<0.05$ were considered statistically significant.

\section{Results}

\section{Effect of RA treatment on NIS and PDS mRNA expression and radioiodine uptake}

To evaluate the participation of NIS and PDS in $\mathrm{I}_{2}$ uptake, the MCF-7 were treated with and without $1 \mu \mathrm{M}$ RA for $48 \mathrm{~h}$. Figure 1 shows that only untreated MCF-7 cells express PDS mRNA and that its expression does not change after RA treatment. In contrast, untreated MCF-7 does not express NIS mRNA, but its expression was induced by RA treatment. When radioiodine uptake was measured as shown in Fig. 2A, the MCF-7 cells without RA (NIS - ) captured a minimal percentage of $\mathrm{I}^{-}$at $15 \mathrm{~min}$. When MCF-7 cells were treated with RA $(\mathrm{NIS}+),{ }^{125} \mathrm{I}^{-}$uptake increased gradually (Fig. 2A). For comparison, the cells with or without RA captured five times more $\mathrm{I}_{2}$ than $\mathrm{I}^{-}$between 5 and $15 \mathrm{~min}$. After 60 min of $\mathrm{I}_{2}$ uptake, $10 \%$ of the radioactivity remained within the cells suggesting $\mathrm{I}_{2}$ incorporation (Fig. 2B). As a non-mammary gland cell control, we used NIH3T3 cells, which neither express NIS mRNA nor capture $\mathrm{I}^{-}$ (Tong et al. 1997). As expected, only basal $\mathrm{I}^{-}$uptake was observed (Fig. 2A). Although these cells capture a significant amount of $\mathrm{I}_{2}$, it is released completely by 60 min (Fig. 2B).

\section{Kinetics of $\mathrm{I}_{2}$ uptake}

The initial velocity of $\mathrm{I}_{2}$ uptake was determined using 5-min incubation in $0.1-10 \mu \mathrm{M} \mathrm{I}_{2}$ and $0.005 \mu \mathrm{Ci}^{125} \mathrm{I}_{2}$. The data show that the $\mathrm{I}_{2}$ transport process was saturated above $5 \mu \mathrm{M} \mathrm{I}_{2}$ (Fig. 3A). A LineweaverBurke plot yielded the apparent $K_{\mathrm{m}}$ of $0.91 \mu \mathrm{M}$ and a $V_{\max }$ of $1.13 \mathrm{pmol} / \mathrm{min}$ per $10^{4}$ cells (Fig. 3B), indicative of a high-affinity and high-capacity system.

\section{Dependence of $\mathrm{I}_{2}$ uptake on NIS and PDS transporters}

MCF-7 cells with and without RA treatment were analyzed in the presence of different doses of DIDS or

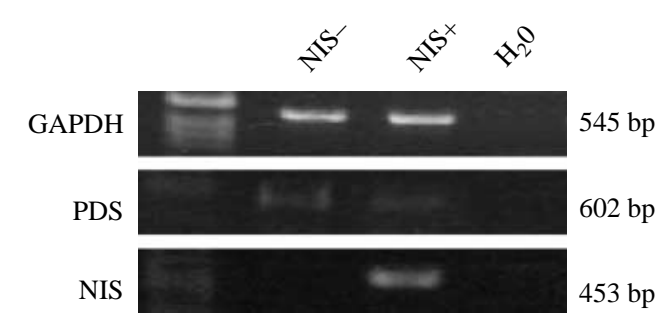

Figure 1 Expression of NIS and PDS mRNAs in MCF-7 cells. Representative electrophoresis (one of the three experiments with similar results). RT-PCR of total RNA from untreated cells $(\mathrm{NIS}-)$ or cells treated with $1 \mu \mathrm{M}$ RA (NIS + ) for $48 \mathrm{~h}$. GAPDH mRNA was used as internal control for normalization purposes. $\mathrm{H}_{2} \mathrm{O}$, water with all the PCR reagents except $\mathrm{RT}$. 

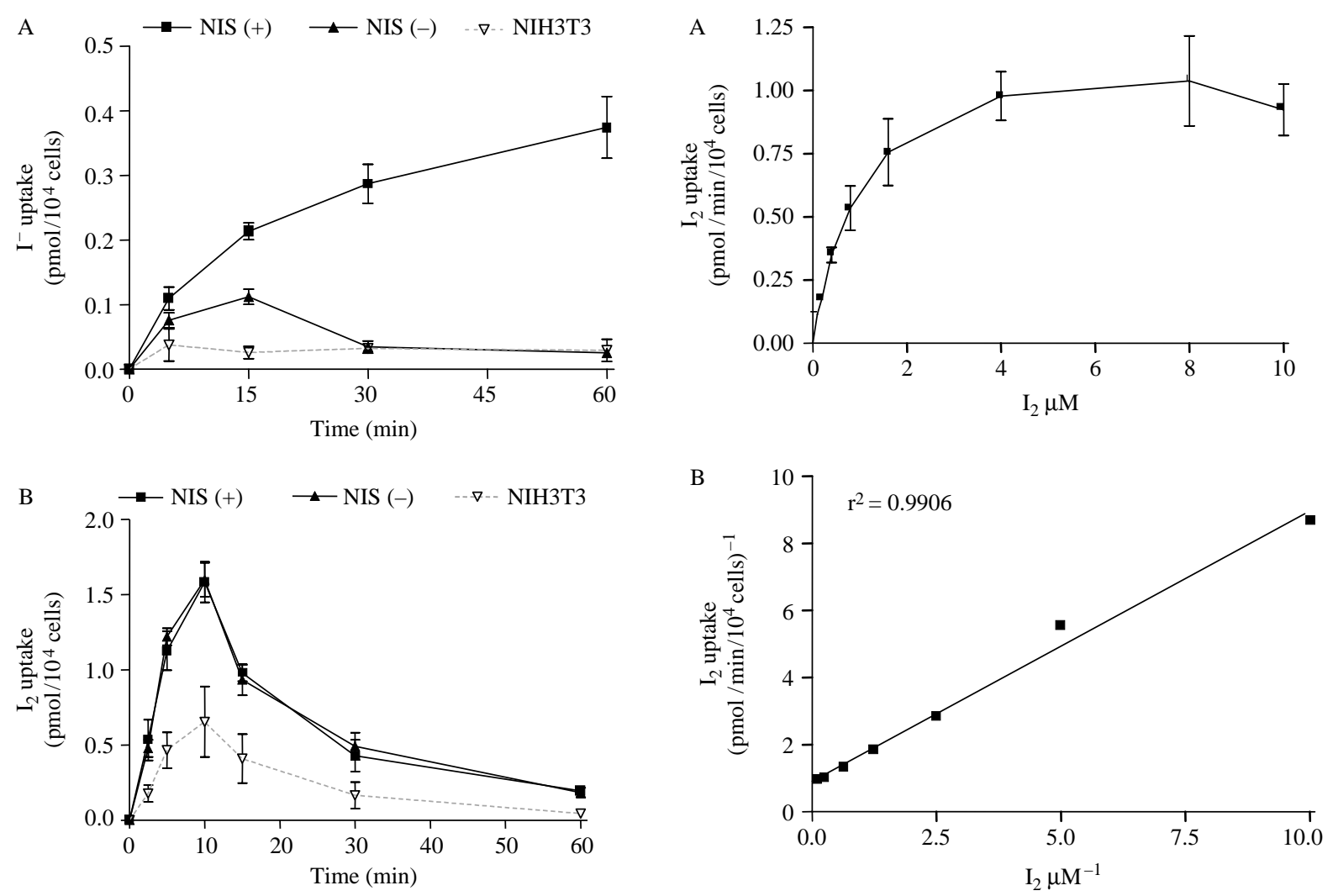

Figure 2 Time-course of accumulation of different iodine forms in NIH3T3 and MCF-7 cells, with or without NIS expression. NIS $(+)$ cells were incubated with $1 \mu \mathrm{M}$ RA for $48 \mathrm{~h}$ to induce expression. All groups were treated with $1.25 \mathrm{mCi} / \mathrm{mmol}^{125} \mathrm{I}^{-}$ or ${ }^{125} \mathrm{I}_{2}$ as indicated in Materials and methods. Radioiodine was determined with a $\gamma$-counter. $A,{ }^{125} \mathrm{I}^{-}$uptake. $\mathrm{B},{ }^{125} \mathrm{I}_{2}$ uptake. The experiments were done in duplicate and repeated five times. Values are expressed as mean \pm s.D.

$\mathrm{KClO}_{4}$. Figure 4A shows that, $1 \mathrm{mM}$ DIDS and $30 \mu \mathrm{M}$ $\mathrm{KClO}_{4}$ inhibited ${ }^{125} \mathrm{I}^{-}$uptake by over $50 \%$, and with both drugs together the inhibition reached $70 \%$. In contrast, they had no inhibitory effect on ${ }^{125} \mathrm{I}_{2}$ uptake (Fig. 4B).

\section{Effect of transcription, translation, and metabolic inhibition on $\mathrm{I}_{2}$ uptake}

RNA and protein synthesis were inhibited by a preincubation with $5 \mu \mathrm{g} / \mathrm{ml} \alpha$-amanitin and CHX respectively. ${ }^{125} \mathrm{I}_{2}$ uptake was not inhibited by $\alpha$-amanitin, whereas CHX caused 55\% inhibition at 60 and $120 \mathrm{~min}$ (Fig. 5). The effect of metabolic inhibition on iodine uptake was measured with $10 \mathrm{mM}$ sodium azide (electron transport inhibitor; Harvey et al. 1999) or $10 \mu \mathrm{M}$ thimerosal $\left(\left(\mathrm{Na}^{+} / \mathrm{K}^{+}\right)\right.$-ATPase inhibitor; Lewis \& Bowler 1983). Figure 6 shows that ${ }^{125} \mathrm{I}^{-}$uptake was $40 \%$ inhibited with both treatments; in contrast, neither inhibitor affected the capture of ${ }^{125} \mathrm{I}_{2}$.

Figure 3 Kinetics of $\mathrm{I}_{2}$ uptake. A, Michaelis-Menten kinetics expressed as mean \pm s.D. $(n=3)$. Cells were incubated with $0.005 \mu \mathrm{Ci}$ of ${ }^{125} \mathrm{I}_{2}$ in $0.01-10 \mu \mathrm{M}$ unlabeled $\mathrm{I}_{2}$ at $37^{\circ} \mathrm{C}$ for $5 \mathrm{~min}$, $\mathrm{B}$, Lineweaver-Burke double-reciprocal plot. The data are representative of three independent experiments. Each point is the mean of triplicate wells.

\section{Organification of $\mathrm{I}_{2}$ or $\mathrm{I}^{-}$}

Figure 7 shows the radiolabeled $I_{2}$ associated with protein (TCA precipitation) and lipid fractions at 15 and $60 \mathrm{~min}$. The total radioactivity in the protein and lipid fractions represents $10-15$ or $87-90 \%$ of the total radiolabeled $I_{2}$ taken up by the cells at 15 or $60 \mathrm{~min}$ respectively. These incorporations were not affected by PTU treatment. In contrast, only a small quantity of the internalized $\mathrm{I}^{-}$was incorporated into lipids, and no radioactivity was found in the protein fraction. Equal amounts of protein were separated on SDS-PAGE, and a representative experiment is shown in Fig. 8. Proteins of $18-20 \mathrm{kDa}$ were labeled with ${ }^{125} \mathrm{I}_{2}$, but no proteins were labeled using ${ }^{125} \mathrm{I}^{-}$. Iodinated lipids were separated by TLC analysis in parallel with the standard samples of 6-IL (unlabeled), $6-{ }^{125} \mathrm{IL}$ (labeled), and AA and were visualized with $\mathrm{I}_{2}$ vapor or autoradiography. Representative results shown in Fig. 9 indicate that some of the iodinated lipid from ${ }^{125} \mathrm{I}_{2}$-treated cells comigrated with the 6-IL standard, whereas with ${ }^{125} \mathrm{I}^{-}$no discrete radioactive spots were 

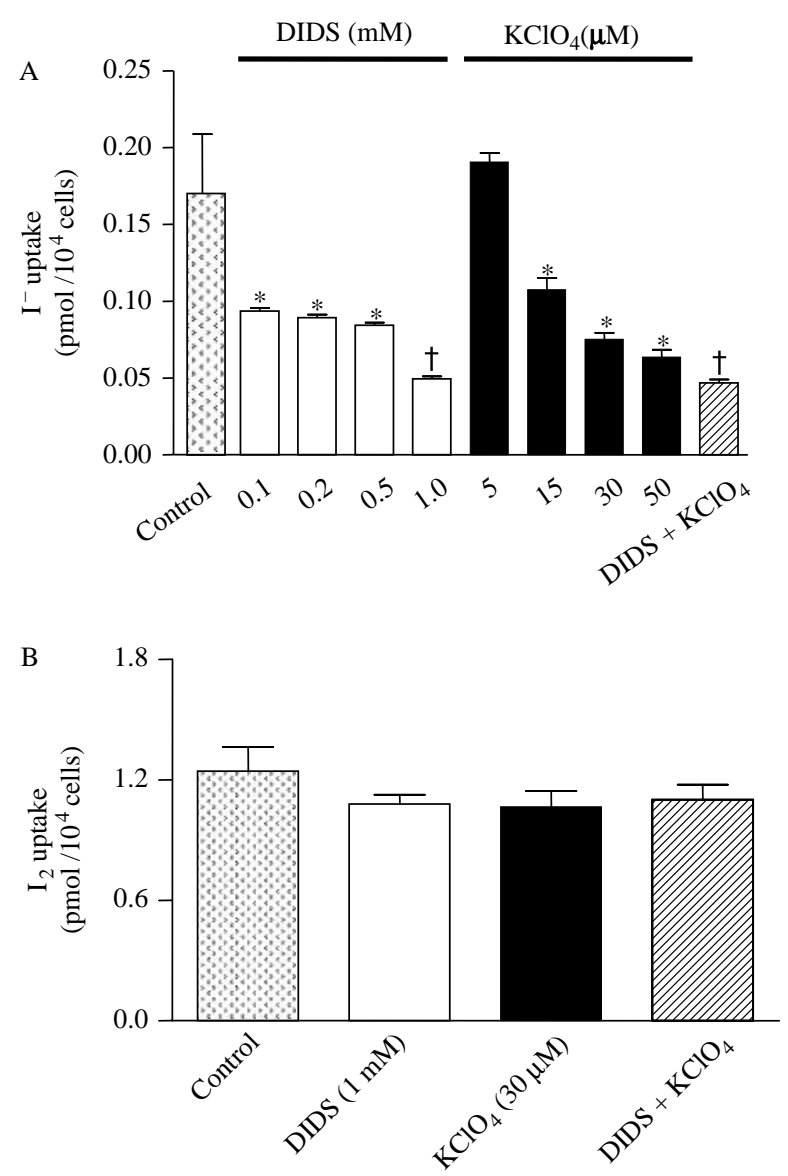

Figure 4 Effect of PDS and NIS inhibitors on $\mathrm{I}^{-}$and $\mathrm{I}_{2}$ uptake. After $48 \mathrm{~h}$ with (NIS +) or without $1 \mu \mathrm{M} \mathrm{RA}(\mathrm{NIS}-)$, cells were incubated with the indicated concentrations of DIDS and $\mathrm{KClO}_{4}$ for $30 \mathrm{~min}$, then for 15 min with $\mathrm{HBSS}$ medium containing $1.25 \mathrm{mCi} / \mathrm{mmol}^{125} \mathrm{I}^{-}$or ${ }^{125} \mathrm{I}_{2}$ and DIDS or $\mathrm{KCIO}_{4}$. A, Effect of varying concentrations of DIDS and $\mathrm{KCIO}_{4}$ on I ${ }^{-}$uptake in NIS + MCF-7 cells. B, Effect of DIDS and $\mathrm{KClO}_{4}$ on $\mathrm{I}_{2}$ uptake in NIS - MCF-7 cells. Data are mean \pm s.D. $(n=5)$. ${ }^{\star} P<0.05 ;{ }^{\dagger} P<0.01$, when compared with control cells.

found. In addition, the incorporation of ${ }^{125} \mathrm{I}_{2}$ was not significantly affected by $100 \mu \mathrm{M}$ PTU (Figs 8 and 9).

\section{Cell proliferation}

The effects of non-radioactive $\mathrm{KI}, \mathrm{I}_{2}$, or 6-IL on MCF-7 cell proliferation were investigated using the Trypan Blue exclusion assay. As shown in Fig. 10, incubation with either $\mathrm{I}_{2}$ or 6-IL for $72 \mathrm{~h}$ reduced cell proliferation in a dose-dependent manner. The inhibition was statistically significant with 20 and $100 \mu \mathrm{M} \mathrm{I}_{2}$ and with $0.1,0.5$, and $1 \mu \mathrm{M}$ 6-IL. Figure 11A shows the time-dependent effect of $\mathrm{I}_{2}$ on proliferation of MCF-7 and NIH3T3 cells. After 48 -h treatment with $20 \mu \mathrm{M} \mathrm{I}_{2}$, there was a significant reduction in MCF-7 cell numbers compared with untreated MCF-7 cells. The effect on proliferation of MCF-7 cells treated with 6-IL was significant beginning at $24 \mathrm{~h}$ (Fig. 11A). In contrast, NIH3T3 cell proliferation was not inhibited with $20 \mu \mathrm{M} \mathrm{I}_{2}$ (Fig. 11A). Similar effects were observed using the MTT proliferation assay in MCF-7 and NIH3T3 cells treated with $\mathrm{I}_{2}$ (Fig. 11B).

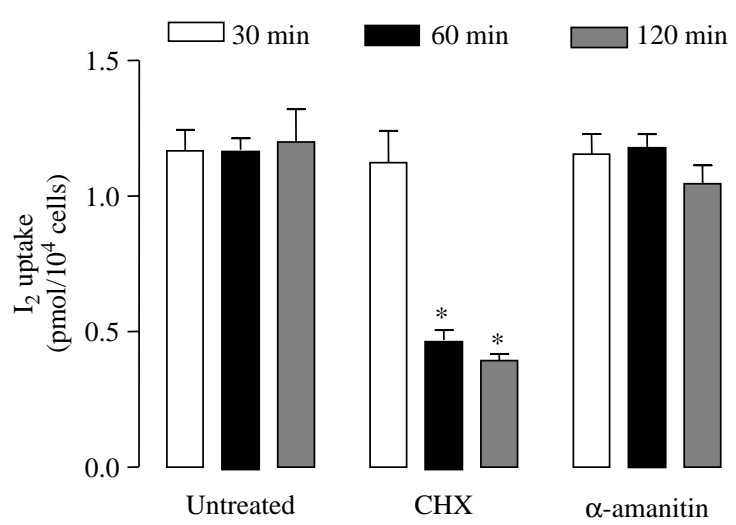

Figure 5 Effect of inhibition of RNA and protein synthesis on $\mathrm{I}_{2}$ uptake. Cells were preincubated for $5 \mathrm{~min}$ with $5 \mu \mathrm{g} / \mathrm{ml}$ $\alpha$-amanitin or cycloheximide (CHX). Cells were then incubated with $1.25 \mathrm{mCi} / \mathrm{mmol}^{125} \mathrm{I}_{2}$ at $37^{\circ} \mathrm{C}$ for $15 \mathrm{~min}$. Data are mean \pm s.D. $(n=3) .{ }^{*} P<0.05$ versus control cells. 


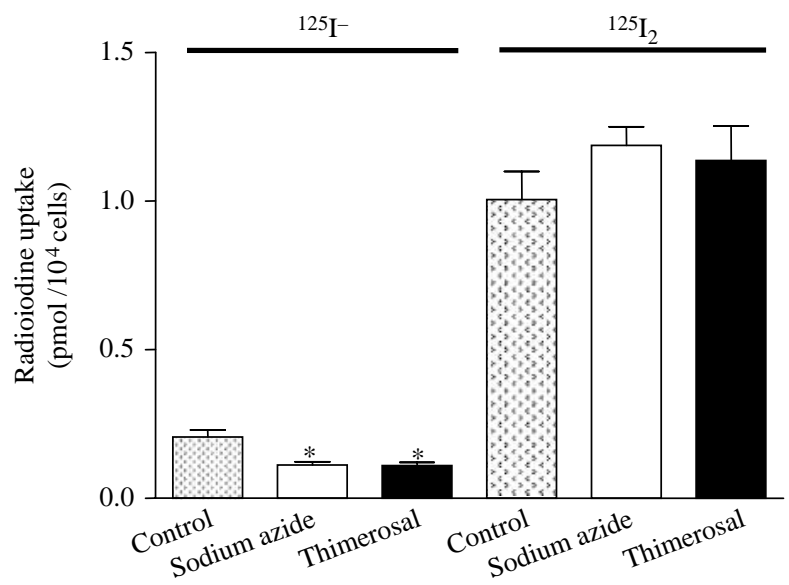

Figure 6 Energy requirement of $\mathrm{I}_{2}$ uptake in NIS + MCF-7 cells. The cells were untreated or treated with $10 \mathrm{mM}$ sodium azide or thimerosal for $30 \mathrm{~min}$. After washing, they were incubated with $1.25 \mathrm{mCi} / \mathrm{mmol}{ }^{125} \mathrm{I}_{2}$ or ${ }^{125} \mathrm{I}^{-}$at $37^{\circ} \mathrm{C}$ for $15 \mathrm{~min}$. Data are mean \pm s.D. $(n=3) .{ }^{\star} P<0.05$ versus control cells.

\section{Discussion}

The present work shows for first time that the capture of $\mathrm{I}_{2}$ occurs by a mechanism different from the transport of $\mathrm{I}^{-}$. Previous studies have demonstrated that NIS and PDS transporters are involved in $\mathrm{I}^{-}$ uptake in both thyroid and mammary glands (Carrasco 2000, Rillema \& Hill 2003a). In the present study, only RA-treated MCF-7 cells showed NIS mRNA expression and $\mathrm{I}^{-}$uptake, confirming that iodide internalization requires NIS (Kogai et al. 2000). Our findings show that in MCF-7 cells, with or without RA (NIS + or NIS - respectively), $\mathrm{I}_{2}$ uptake is five times greater than $\mathrm{I}^{-}$and has a peak within 5 and $15 \mathrm{~min}$, suggesting that $I_{2}$ uptake does not require the NIS transporter. The NIH3T3 cells showed a similar pattern of $\mathrm{I}_{2}$ uptake, but its capture was significantly lower. MCF-7 cells also express the PDS transporter, which is DIDS sensitive (Royaux et al. 2000, Rillema \& Hill $2003 b$ ). Neither $\mathrm{KClO}_{4}$ nor DIDS inhibited $\mathrm{I}_{2}$ uptake in NIS + MCF-7 cells, demonstrating that NIS and PDS do not participate in $\mathrm{I}_{2}$ uptake. Our results suggest that $\mathrm{I}_{2}$ uptake is mediated by a common facilitated transporter in mammary and non-mammary cells; however, in NIH3T3 cells the $\mathrm{I}_{2}$ uptake is reduced, and $\mathrm{I}_{2}$ not retained within the cell.

Our results show the existence of a distinct uptake system for $\mathrm{I}_{2}$ that is saturable $(>5 \mu \mathrm{M})$ and has a high affinity $\left(K_{\mathrm{m}}\right.$ of $\left.0.91 \mu \mathrm{M}\right)$ and high velocity $\left(V_{\max }\right.$ of $1.13 \mathrm{pmol} / \mathrm{min}$ per $10^{4}$ cells), contrasting with the low affinity and high velocity of $\mathrm{I}^{-}$uptake in NIS + MCF-7 cells $\left(K_{\mathrm{m}}\right.$ of $21.9 \mu \mathrm{M}$ and $V_{\max }$ of $2.17 \mathrm{pmol} / \mathrm{min}$ per $10^{4}$ cells; Kogai et al. 2000). In addition, $\mathrm{I}_{2}$ uptake is dependent on protein synthesis, but it is independent of ATP and $\mathrm{Na}^{+} / \mathrm{K}^{+}$-ATPase. These characteristics were reported by Rillema \& Hill (2003b) for $\mathrm{I}^{-}$uptake by PDS, the DIDS-sensitive transporter. However, $I_{2}$ uptake by MCF-7 cells was not inhibited with DIDS. $\mathrm{I}_{2}$ uptake followed Michaelis-Menten kinetics, but ATP and $\mathrm{Na}^{+} / \mathrm{K}^{+}$-ATPase were not required, suggesting a facilitated diffusion mechanism, according to the definition by Lobban et al. (1985). $\mathrm{I}_{2}$ uptake showed similar characteristics in brown algae, where it was shown that after oxidation of $\mathrm{I}^{-}$to $\mathrm{I}_{2}$ or $\mathrm{HIO}$ by haloperoxidases, oxidized iodine is captured by a facilitated diffusion system (Küpper et al. 1998).

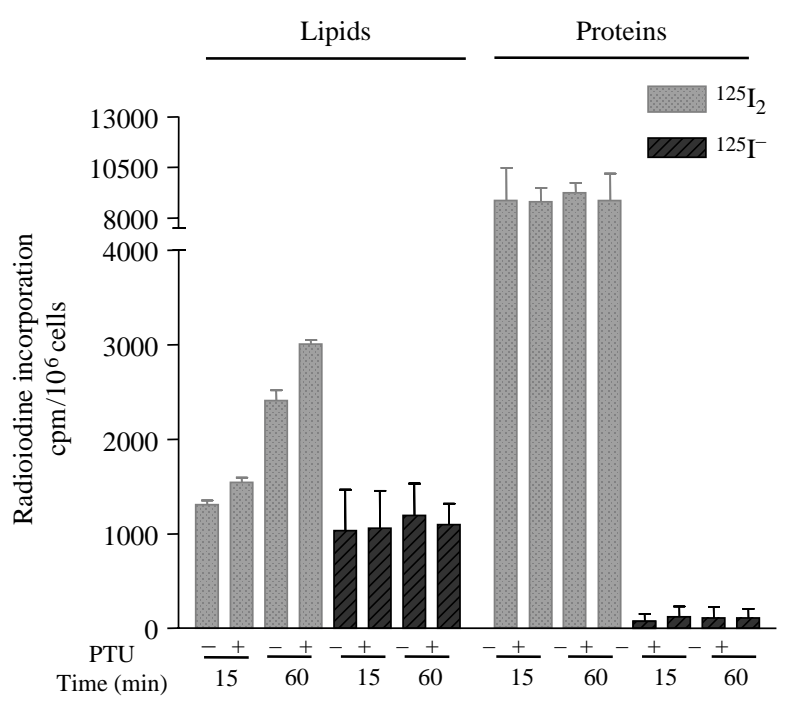

Figure 7 Organification of $\mathrm{I}^{-}$versus $\mathrm{I}_{2}$ into proteins and lipids. NIS - MCF-7 cells were incubated with or without $100 \mathrm{mM} \mathrm{PTU}$ for $5 \mathrm{~min}$ before adding $1.25 \mathrm{mCi} / \mathrm{mmol}^{125} \mathrm{I}_{2}$ or ${ }^{125} \mathrm{I}^{-}$. The radioactivity of protein (TCA precipitate) and lipids (chloroform fraction) was expressed as c.p.m. $/ 10^{4}$ cells. Data are mean \pm s.D. $(n=3)$. 


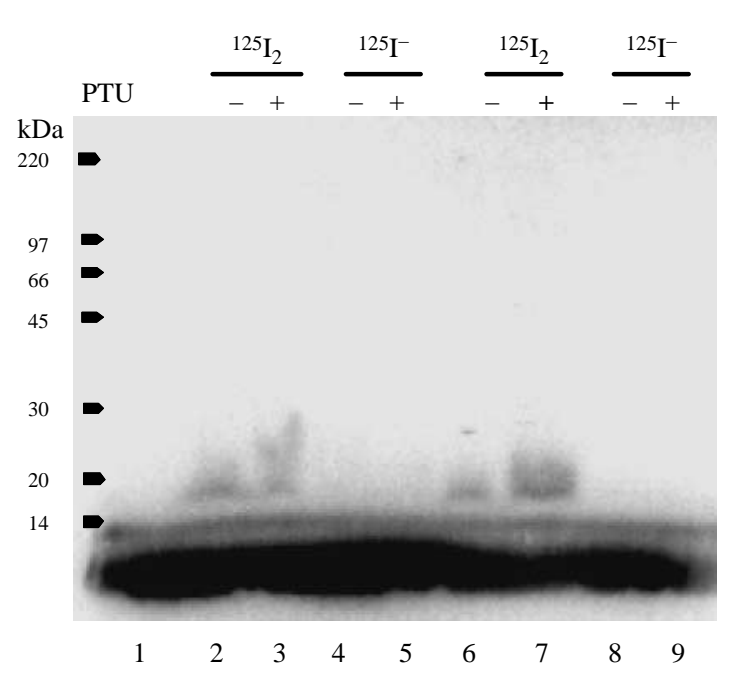

Figure 8 Analysis by SDS-PAGE of iodinated proteins from NIS - MCF-7 cells incubated with ${ }^{125} \mathrm{I}^{-}$or ${ }^{125} \mathrm{I}_{2}$. Cells were incubated with or without $100 \mathrm{mM}$ PTU for 5 min before adding $1.25 \mathrm{mCi} / \mathrm{mmol}^{125} \mathrm{I}_{2}$ or ${ }^{125} \mathrm{I}^{-}$. Aliquots containing $50 \mu \mathrm{g}$ protein were separated by $12 \%$ SDS-PAGE. lodinated proteins were detected by autoradiography. 1 , molecular weight markers; 2,3 , 4 , and 5 , radioiodinated proteins at $15 \mathrm{~min} ; 6,7,8$, and 9 , radioiodinated proteins at $60 \mathrm{~min}$. The figure is representative of electrophoresis of proteins labeled in five independent experiments.

Several studies have reported that $\mathrm{I}^{-}$needed to be oxidized by peroxidases, such as thyro-, myelo-, eosinophil-, and lactoperoxidases, and these, in turn, induced cytotoxic effects (Strum 1978, Boeynaems \& Hubbard 1980, Turk et al. 1983, Ekholm \& Bjorkman 1997). A specific species of oxidized iodine has not yet been identified, but several candidates exist, such as $\mathrm{I}^{+}$ (iodinium), $\mathrm{I}^{0}$ (iodine free radical), $\mathrm{IO}^{-}$(hypoiodite), $\mathrm{HIO}$, and $\mathrm{I}_{2}$ (Smyth 2003). Our results of organification in mammary cells show iodination of proteins with low-molecular weight. In lactating mammary gland, iodine is incorporated into the milk protein, casein (Strum 1978, Shah et al. 1986), which is expressed by MCF-7 cells (Constantinou et al. 1998). It is possible that the lack of casein expression in mouse fibroblast cells explains why $I_{2}$ is not retained within these cells. In mammary cells, we show that protein iodination took place in the presence of PTU, indicating that $\mathrm{I}_{2}$ organification does not require peroxidase activity. This result is consistent with previous studies showing that $\mathrm{I}_{2}$ generates thyroxine (T4) in the absence of peroxidase (Thrall et al. 1992). In contrast, $\mathrm{I}^{-}$ treatment did not generate iodinated proteins, which can be explained by the absence of peroxidase activity in MCF-7 cells (Kogai et al. 2000). Although we found radioactivity in the lipid fraction from $\mathrm{I}^{-}$treated cells, when we analyzed it by TLC and autoradiography no iodinated spots were identified. Thus, the ${ }^{125} \mathrm{I}^{-}$we found in the lipid fraction might reflect a non-covalent interaction. It has been shown that $\mathrm{I}^{-}$can bind to the lipid bilayer surface (Langner \& Hui 1991). In contrast, lipids from cells treated with $\mathrm{I}_{2}$ showed a migration similar to the 6-IL standard, suggesting that $\mathrm{I}_{2}$ treatment could generate this type of iodolactone. In the thyroid gland, the antiproliferative and/or apoptotic effect of $\mathrm{I}^{-}$treatment is mediated by iodinated arachidonic acid derivatives such as 6-IL or iodohexadecanal (Dugrillon et al. 1990, Pisarev et al. 1994, Langer et al. 2003). In vivo iodolipid formation in mammary gland treated with $\mathrm{I}_{2}$ has not been investigated. Data generated in our laboratory showed a reduction in mammary tumors without changes in thyroid status (García-Solís et al. 2005a,b), suggesting a specific $\mathrm{I}_{2}$ effect only in tumoral tissue in rats. Several studies have reported elevated prostaglandin levels in breast cancer but not in normal mammary gland (Tan et al. 1974, Bennett et al. 1977, Rolland et al. 1980).
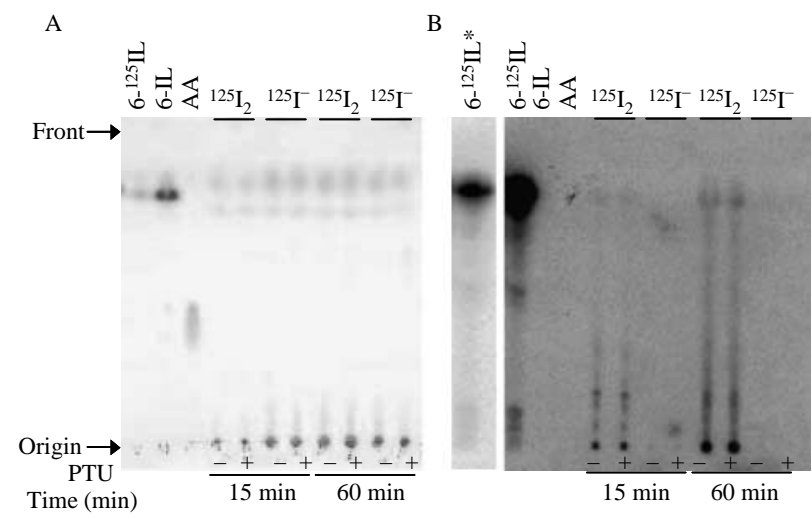

Figure 9 Analysis of iodinated lipids from NIS - MCF-7 cells incubated with ${ }^{125} \mathrm{I}^{-}$versus ${ }^{125} \mathrm{I}_{2}$. Cells were incubated with or without $100 \mathrm{mM}$ PTU $5 \mathrm{~min}$ before adding $1.25 \mathrm{mCi} / \mathrm{mmol}^{125} \mathrm{I}_{2}$ or ${ }^{125} \mathrm{I}^{-}$. A, Representative TLC with iodinated lipids revealed by iodine vapors. B, lodinated lipids on the same TLC detected by autoradiography after 15-h exposure. The experiment is representative of three different assays. $6{ }^{-125} \mathrm{IL}$, labeled 6 -iodolactone; $6-\mathrm{IL}^{*}$, autoradiography of $6{ }^{-125} \mathrm{IL}$ of the same TLC exposed only for $6 \mathrm{~h}$. 


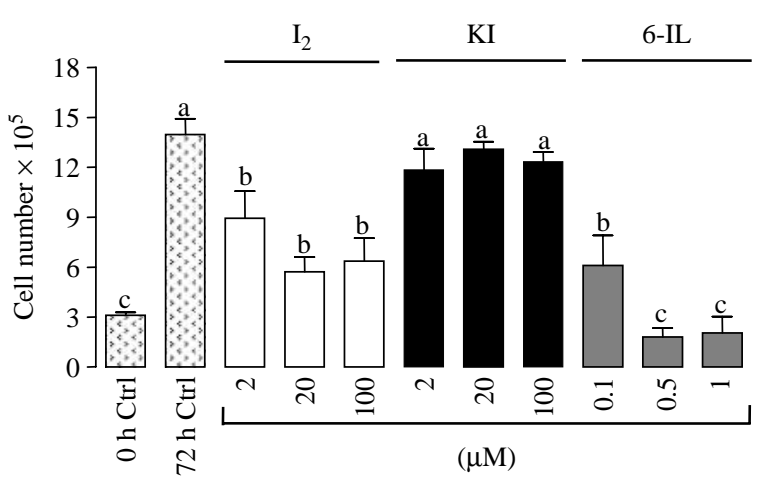

Figure 10 Dose-dependent effects of $\mathrm{KI}, \mathrm{I}_{2}$, and the 6-IL on the proliferation of NIS - MCF-7 cells. Cells were incubated with different concentrations of $\mathrm{KI}, \mathrm{I}_{2}$, and $6-\mathrm{IL}$ for $72 \mathrm{~h}$. After the cells were stained with $0.4 \%$ Trypan Blue, viable cells were counted with a hemocytometer under the microscope. Data are expressed as mean \pm s.D. $(n=5)$. Different letters indicate significant differences between groups $(P<0.05)$.

Prostaglandins are produced from AA by the enzyme cyclooxygenase, indicating the presence of high levels of AA in breast tumors. It is possible that these high levels of AA, and the iodolipids formed from them, may explain the specific effect of $\mathrm{I}_{2}$ in tumoral cells. This hypothesis is being explored in our laboratory.

We also examined the effects of non-radioactive KI, $\mathrm{I}_{2}$, or 6-IL, and we found that $\mathrm{I}_{2}$ and 6-IL treatments inhibited the proliferation rate of mammary cells in a dose-dependent manner at $72 \mathrm{~h}$. When we analyzed the time dependence, $\mathrm{I}_{2}$ and 6-IL treatments inhibited proliferation within $24 \mathrm{~h}$, but the mechanism of this inhibition has not been studied. In thyroid gland, iodine treatment arrested the cell cycle at the GO/G1 and G2/M phases (Tramontano et al. 1989, Smerdely et al. 1993). Other studies have shown an apoptotic effect induced by iodine excess in cultured thyrocytes. This effect did not involve changes in the antitumor protein p53 and did not require expression of apoptosis-related proteins, such as $\mathrm{Bax}, \mathrm{Bcl} 2$, or $\mathrm{Bcl} \mathrm{XL}$ (Vitale et al. 2000). With regard to the mammary gland, several authors have proposed that iodine deficiency alters the structure and function of human and rat mammary cells, and that $\mathrm{I}_{2}$ is more effective than $\mathrm{I}^{-}$in diminishing ductal hyperplasia and perilobular fibrosis (Ghent et al. 1993, Eskin et al. 1995). Studies in our laboratory have shown that chronic administration of $\mathrm{I}_{2}$ but not $\mathrm{I}^{-}$has a potent antineoplasic effect at the promotional level of mammary cancer and does not involve changes in the expression of p53 (García-Solís et al. 2005a,b). In addition to this, a recent report showed that the $\mathrm{I}_{2}$ effect in human breast cancer cell lines involves the activation and translocation of Bax from mitochondria, allowing the release and translocation of
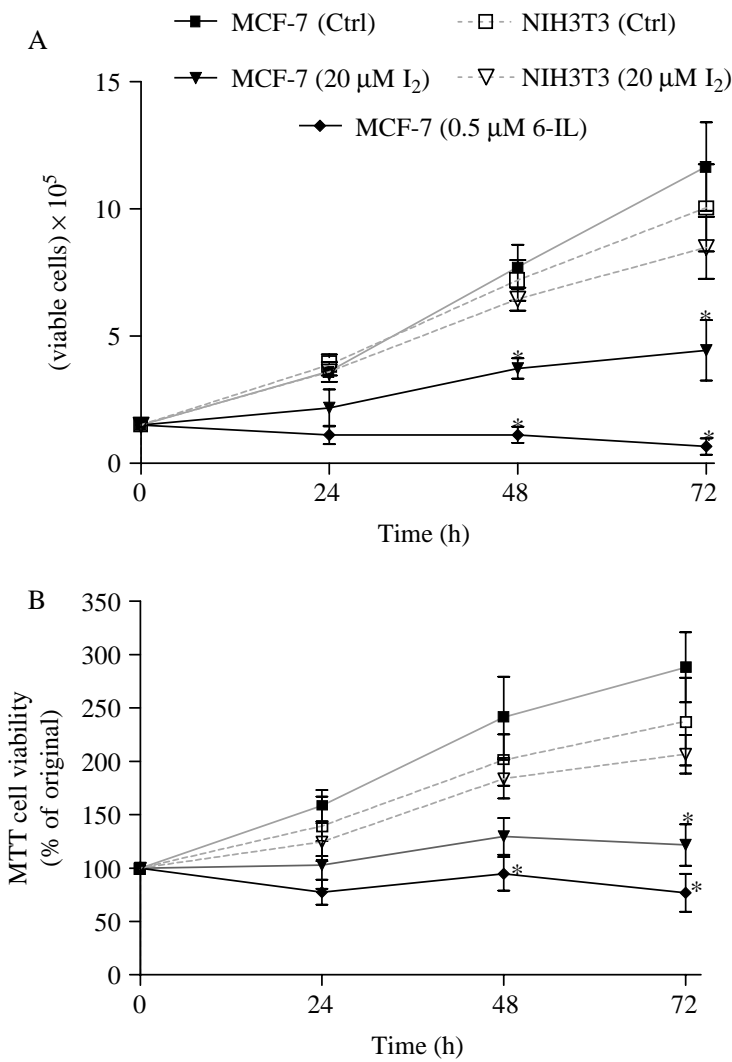

Figure 11 Proliferation curves of cells NIH3T3 and MCF-7 in the presence of $\mathrm{I}_{2}$, or 6 -IL. After the indicated times aliquots were removed, and the cell number was determined by $(A)$ direct counting using Trypan Blue exclusion, or (B) the MTT assay. Data are expressed as mean \pm s.D. $(n=5)$. ${ }^{\star} P<0.05$ versus control cells.

AIF to the nucleus, where it brings about nuclear fragmentation independent of caspases (Shrivastava et al. 2006). In the present study, we show that $I_{2}$ treatment diminishes cell proliferation and is accompanied by iodination of lipids and proteins. We propose that the peroxisome proliferator-activated receptor (PPAR), a ligand-dependent transcription factor, can participate in the antiproliferative $I_{2}$ effect. It is noteworthy that polyunsaturated fatty acids, including linoleic acid, eicosanoids, and AA (6-IL precursor), are endogenous PPAR ligands (Kliewer et al. 1997). PPAR ligands are involved in the regulation of cellular differentiation, cell cycle control, and apoptosis unrelated to p53 (Rosen \& Spiegelman 2001, Shen \& Brown 2003). Our results show that $\mathrm{I}_{2}$ treatment has an antiproliferative effect on MCF-7 cells, and they suggest the formation of 6-IL, which may mediate this effect; however, more detailed investigations are needed to elucidate the molecular mechanism of the actions of iodine derivatives in proliferation and/or apoptosis. 
Taken together, these results demonstrate that $\mathrm{I}_{2}$ uptake does not require NIS or PDS transporters and suggest that $I_{2}$ is taken up by a facilitated diffusion system and is subsequently bound to proteins or lipids that inhibit cell proliferation.

Finally, our findings both in vivo (García-Solís et al. $2005 a$ ) and in vitro (present work), as well the recent report of Shrivastava et al. (2006) showing that the antiproliferative effect of $\mathrm{I}_{2}$ treatment is exerted only in tumoral cells, lead us to propose that $\mathrm{I}_{2}$ treatment should be tested in clinical trials as an adjuvant of breast cancer therapy.

\section{Acknowledgments}

The authors are grateful to Dr Guillermo Juvenal for advice on 6-iodolactone synthesis; Olivia VázquezMartínez, and Felipe Ortíz for technical assistance, Pilar Galarza for bibliographic assistance, Leonor Casanova and Rafel Silva for academic support. We also thank Nydia Hernández, Leopoldo Gonzalez, and Lourdes Lara for image advice, Alberto Lara and Omar González for computer assistance, and Anaid Antaramian for molecular biology assistance. We thank Irene Xochihua for helping to prepare the manuscript, and Dr Dorothy Pless for proof reading. O ArroyoHelguera was a graduate student of UNAM and received a fellowship from CONACYT 171250. This work was partially supported by grants: UNAM/DGAPA IN224602 and CONACYT 44976-M. The authors declare that there is no conflict of interest that would prejudice the impartiality of this scientific work.

\section{References}

Aceves C, Anguiano B \& Delgado G 2005 Is iodine a gatekeeper of the integrity of the mammary gland? Journal of Mammary Gland Biology and Neoplasia 2 189-196.

Arroyo-Helguera O, Mejía-Viggiano C, Varela-Echavarría A, Cajero-Juárez M \& Aceves C 2005 Regulatory role of the $3^{\prime}$ untranslated region $\left(3^{\prime} \mathrm{UTR}\right)$ of rat $5^{\prime}$ deiodinase (D1). Effects on messenger RNA translation and stability. Endocrine 27 219-225.

Bennett A, Charlier EM, McDonald AM, Simpson JS, Stamford IF \& Zebro T 1997 Prostaglandins and breast cancer. Lancet 2 624-626.

Bligh EG \& Dyer WJ 1959 A rapid method of total lipid extraction and purification. Canadian Journal of Biochemistry and Physiology 37 911-917.

Boeynaems JM \& Hubbard WC 1980 Transformation of arachidonic acid into an iodolactone by rat thyroid. Journal of Biological Chemistry 225 9001-9004.
Carrasco N 2000 Thyroid iodide transport: the $\mathrm{Na}^{+} / \mathrm{I}^{-}$ symporter (NIS). In Werner \& Ingbar's The Thyroid: A Fundamental and Clinical Text, 8th edn, pp 52-61. Eds LE Braverman R Utiger. Philadelphia, PA, USA: Lippincott Williams \& Williams.

Constantinou AI, Krygier AE \& Mehta RR 1998 Genistein induces maturation of cultured human breast cancer cells and prevents tumor growth in nude mice. American Journal of Clinical Nutrition 68 426S-430S. Dugrillon A, Bechtner G, Uedelhoven WM, Weber PC \& Gartner T 1990 Evidence that an iodolactone mediates the inhibitory effect of iodide on thyroid cell proliferation but not on adenosine $3^{\prime}-5^{\prime}$-monophosphate formation.

Endocrinology 127 337-343.

Ekholm R \& Bjorkman U 1997 Glutathione peroxidase degrades the intracellular hydrogen peroxide and thereby inhibits intracellular protein iodination in thyroid ephitelium. Endocrinology 138 2871-2878.

Eskandari S, Loo DD, Dai G, Levy O, Wright EM \& Carrasco N 1997 Thyroid Na ${ }^{+/ I-}$ symporter. Mechanism, stoichiometry, and specificity. Journal of Biological Chemistry 272 27230-27238.

Eskin BA, Grotkowski CE, Connolly CP \& Ghent WR 1995 Different tissue responses for iodine and iodide in rat thyroid and mammary glands. Biological Trace Element Research 49 9-19.

García-Solís P, Alfaro Y, Anguiano B, Delgado G \& Guzmán C $2005 a$ Inhibition of induced-MNU mammary carcinogenesis by molecular iodine $\left(\mathrm{I}_{2}\right)$ but not iodide $\left(\mathrm{I}^{-}\right)$treatment. Evidence that $\mathrm{I}_{2}$ prevents cancer promotion. Molecular and Cellular Endocrinology 236 49-57.

García-Solís P, Delgado G, Anguiano B \& Aceves C $2005 b$ Differential uptake and signaling of molecular iodine $\left(\mathrm{I}_{2}\right)$ in lactating, virgin, or neoplastic mammary glands. 13th International Thyroid Meeting, Buenos Aires, Arg. (Abstract). Thyroid 15 (Supplement 1) S-128.

Ghent WR, Eskin BA, Low DA \& Hill LP 1993 Iodine replacement in fibrocystic disease of the breast. Cancer Journal of Surgery 36 453-460.

Gillan MP, Sidhave AR, Lee EJ, Rutishauser J, Stephan CW \& Kopp P 2004 Functional characterization of pendrin in a polarized cell system. Evidence for pendrin-mediated apical iodide efflux. Journal of Biological Chemistry 279 13004-13010.

Harvey J, Hardy SC \& Ashford MLJ 1999 Dual actions of the metabolic inhibitor, sodium azide on $\mathrm{K}_{\mathrm{ATP}}$ channel currents in the rat CRI-G1 insulinoma cell line. British Journal of Pharmacology 126 51-60.

Kliewer SA, Sundseth SS, Jones SA, Brown PJ, Wisley GB, Koble CS, Devchand P, Wahli W, Wilson TM, Lenhard JM et al. 1997 Fatty acids and eicosanoids regulate gene expression through direct interaction with peroxisome proliferator-activated receptors $\alpha$ and $\gamma$. PNAS 94 4318-4323.

Kogai T, Schultz JJ, Johnson LS, Huang M \& Brent GA 2000 Retinoic acid induces sodium/iodide symporter gene expression and radioiodide uptake in the MCF-7 breast cancer cell line. PNAS 97 8519-8524. 
Küpper FC, Schweigert N, Ar Cali E, Legendre JM, Vilter H \& Koareg B 1998 Iodine uptake in laminariales involves extracellular, haloperoxidase-mediated oxidation of iodide. Planta 207 163-171.

Langner M \& Hui SW 1991 Iodide penetration into lipid bilayers as a probe of membrane lipid organization. Chemistry and Physics of Lipids 60 127-132.

Langer R, Burzler C, Bechtner G \& Gartner R 2003 Influence of iodide and iodolactones on thyroid apoptosis. Experimental and Clinical Endocrinology and Diabetes 111 325-329.

Lewis RN \& Bowler K 1983 Rat brain $\left(\mathrm{Na}^{+} / \mathrm{K}^{+}\right)$ATPase: modulation of its ouabain-sensitive $\mathrm{K}^{+}$-PNPPase activity by thimerosal. International Journal of Biochemistry 15 5-7.

Lobban CS, Harrison PJ \& Duncan MJ 1985 Nutrients. In The Physiological Ecology of Seaweeds, pp 75-110. Eds CS Lobban, PJ Harrison \& MJ Duncan. Cambridge: Cambridge University Press.

McAlpine RK 1945 The rate of the of oxidation of iodide ion by hydrogen peroxide. Journal of Chemical Education 22 387-390.

Monteagudo ES, Caro HN, Veleiro AS, Pisarev MA \& Burton G 1990 Synthesis and characterization of iodinated derivatives of arachidonic acid. Anales de la Asociación de Química de Argentina 78 31-36.

Pisarev M.A. \& Gartner R. 2000 Autoregulatory actions of iodine. In Werner \& Ingbar's The Thyroid: A Fundamental and Clinical Text, 8th edn, pp 85-90. Eds LE Braverman \& R Utiger. Philadelphia, USA: Lippincott Williams \& Wilkins.

Pisarev MA, Krawiec L, Juvenal GJ, Bocanera LV, Pregliasco LB, Sartorio G \& Chester HA 1994 Studies on the goiter inhibiting action of iodolactones. European Journal of Pharmacology 258 33-37.

Rillema JA \& Hill MA $2003 a$ Prolactin regulation of the pendrin-iodide transporter in the mammary gland. American Journal of Physiology and Endocrinology Metabolism 281 E25-E28.

Rillema JA \& Hill MA 2003b Pendrin transporter carries out iodide uptake into MCF-7 human mammary cancer cells. Experimental Biology and Medicine 228 1078-1082.

Rolland PH, Martin PM, Jacquemier J, Rolland AM \& Toga M 1980 Prostaglandins in human breast cancer: evidence suggesting that an elevated prostaglandin production is a marker of high metastatic potential for neoplastic cells. Journal of the National Cancer Institute 64 1061-1070.

Rosen ED \& Spiegelman BM 2001 PPAR $\gamma$ : a nuclear regulator of metabolism, differentiation, and cell growth. Journal of Biological Chemistry 276 37731-37734.

Royaux IE, Susuki K, Mori A, Katoh R, Everett LA, Kohn LD \& Green ED 2000 Pendrin, the protein encoded by the pendred syndrome gene (PDS), is an apical porter of iodide in the thyroid and is regulated by thyroglobulin in FRTL-5 cells. Endocrinology 141 839-845.
Shah NM, Eskin BA, Krouse TB \& Sparks CE 1986 Iodoprotein formation by rat mammary glands during pregnancy and early postpartum period. Proceedings of the Society for Experimental Biology and Medicine 181 443-449.

Shen Q \& Brown PH 2003 Novel agents for the prevention of breast cancer: targeting transcription factors and signal transduction pathways. Journal of Mammary Gland Biology and Neoplasia 8 45-73.

Shennan DB 2001 Iodide transport in lactating rat mammary tissue via a pathway independent from the $\mathrm{Na}^{+} / \mathrm{I}^{-}$ cotransporter: evidence for sulfate/iodide exchange. Biochemical and Biophysical Research Communications 280 1359-1363.

Shrivastava A, Tiwari M, Sinha RA, Kumar A, Balapure AK, Bajpai VK, Sharma R, Mitra K, Tandon A \& Godbole MM 2006 Molecular iodine induces caspase-independent apoptosis in human breast carcinoma cells involving mitochondria-mediated pathway. Journal of Biological Chemistry 281 19762-19771.

Smerdely P, Pitsiavas V \& Boyages SC 1993 Evidence that the inhibitory effects of iodide on thyroid cell proliferation are due to arrest of the cell cycle at GOG1 and G2M phases. Endocrinology 133 2881-2888.

Smyth PP 2003 Role of iodine in antioxidant defense in thyroid and breast disease. Biofactors 19 121-130.

Soleimani M, Greeley T, Petrovic S, Wang Z, Amlal H, Kopp P \& Burnham CE 2001 Pendrin: an apical $\mathrm{Cl}^{-} / \mathrm{OH}^{-} / \mathrm{HCO}_{3}$ exchanger in the kidney cortex. American Journal of Physiology-Renal Physiology 280 F356-F364.

Strum JM 1978 Site of iodination in lactating mammary gland. Anatomical Record 192 235-244.

Tan WC, Privett OS \& Goldyne ME 1974 Studies of prostaglandins in rat mammary tumors induced by 7,12 dymethyl-benz(a)anthracene. Cancer Research 34 3229-3231.

Tazebay UH, Wapnir IL, Levy O, Dohan O, Zuckier LS \& Zhao QH 2000 The mammary gland iodide transporter is expressed during lactation and in breast cancer. Nature Medicine 6 871-878.

Thrall KD, Sauer RL \& Bull RJ 1992 Evidence of thyroxine formation following iodine administration in SpragueDawley rats. Journal of Toxicology Environmental and Health 37 535-548.

Tong Q, Ryu KY \& Jhiang SM 1997 Promoter characterization of the rat $\mathrm{NA}^{+} / \mathrm{I}^{-}$symporter gene. Biochemical and Biophysical Research Communications 239 34-41.

Tramontano D, Veneziani BM, Lombardi T, Villone G \& Ingbar SH 1989 Iodine inhibits the proliferation of rat thyroid cells in culture. Endocrinology 126 984-992.

Turk J, Henderson WR, Klebanoff SJ \& Hubbard WC 1983 Iodination of arachidonic acid mediated by eosinophil peroxidase, myeloperoxidase and lactoperoxidase. Identification and comparison of products. Biochimica et Biophysica Acta 751 189-200. 
Vitale M, Di Matola T, D’Ascoli F, Salzano S, Bogazzy F, Fenzi G, Martino E \& Rossi G 2000 Iodide excess induces apoptosis in thyroid cells through a p53-independent mechanism involving oxidative stress. Endocrinology 141 598-605.

Wenzel A, Upadhyay G, Schmitt TL \& Loos U 2003

Iodination of proteins in TPO transfected thyroid cancer cells is independent of NIS. Molecular and Cellular Endocrinology 213 99-108.

Zhang L, Sharma S, Zhu LX, Kogai T, Hershman JM, Brent GA, Dubinett SM \& Huang M 2003 Nonradioactive iodide effectively induces apoptosis in genetically modified lung cancer cells. Cancer Research 63 5065-5072. 